\title{
TERTIARY STUDENTS' AWARENESS OF CLIMATE CHANGE: A CASE STUDY OF A SELECTED UNIVERSITY OF TECHNOLOGY
}

\author{
Vuyolwethu Dyani \\ vuyolwethudyani@gmail.com \\ Business Administration \\ Faculty of Business and Management Science \\ Cape Peninsula University of Technology, Cape Town in South Africa
}

\begin{abstract}
Introduction: Climate change (CC) is harming the planet. All of society should be involved in managing climate changes or it will become uncontrollable. Students should not be left out as they are regarded as important to the society and in a good position to deal with the changes because they will become tomorrow's decision makers and influencers.

Problem statement: It is unclear whether students at tertiary institutions are aware of climate change.
\end{abstract}

Aim of study: The aim of the research was to explore the level of climate change awareness of tertiary students.

Research methodology: The research adopted the objectivist ontology. A positivist approach was followed and the research approach was deductive. The intent of the study was to generalise what tertiary students think and know about climate change, therefore, the survey strategy was appropriate. Questionnaires were used to collect data from 603 students who participated in the study. The data were analysed using MS Excel and SPSS available at the university. A factors analysis was also performed. In total, 42 findings were identified.

Ethics: Participants were informed of the purpose of the study and their rights to privacy. No cultural or any other sensitive questions were asked, and participants had the option to participate in the study and withdraw at any time.

Finding: Students are aware of climate change, but more needs to be done to empower students to become advocates of climate change.

Keywords: Climate change, tertiary students, awareness 


\section{Introduction}

This research focuses on tertiary students' awareness of Climate Change (CC). University students' knowledge and awareness of CC is of utmost importance as it equips them with skills to cope with the future impact of CC (Mugambiwa \& Dzomonda, 2018). Climate change has become a reality. It affects everyone in society. According to Jamshidi et al. (2018:1369), CC "is one of the most important environmental problems facing the world today". Rother and Godsmark (2018) state that CC now forms a major part of the global debate. The planet faces a major upheaval in the making and it is essential that all role-players become involved in the battle against negative climate change.

\section{Problem statement}

CC has a detrimental effect on the planet. According to Edwards (2020), the planet is in the midst of CC disaster in slow motion. According to Kennedy and Lindsey (2015), the planet has challenge with CC. CC is the defining health and environmental crisis of the twenty-first century (Gordon, 2020).

Future generations need to be aware of the problem and become involved in the management of CC (O'Brien et al., 2018). Narksompong and Limjirakan (2015) suggest that empowering young people on issues related to CC is essential. Trott (2021) also supports that everyone should become knowledgeable about CC already at childhood. Without the involvement of all the people, and particularly students, the planet will eventually be irrevocably be changed or destroyed (Agboola \& Emmanuel, 2016). Unfortunately, there is little information available on the level of awareness of students on CC and more research needs to be done on the awareness levels of students on CC (Barreda, 2018). It is unclear whether students at tertiary institutions are aware of CC.

\section{Demarcation}

The study focused on tertiary education students. Only one university was selected as a case. Although it is acknowledge that there are many factors affecting CC, only the level of awareness of students at a specific university was studied. Schools and other tertiary institutions such as TVETs were excluded.

\section{Limitations of the research}

The questionnaires used for data collection was prepared in English and this may have been a problem for some students as English is generally a second, or even a fourth language to them .Only students were interviewed. Only one UoT was used. 


\section{Literature review}

$\mathrm{CC}$ affects the everyday life of all the people on the planet. There is a need for a deep understanding of the CC problem and for understanding the human and its relationship with the planet at large. The people of the world need to be involved in the management of CC. In this research, students' levels of CC awareness are explored. To do this, a literature review was done using keywords identified from the title, problem statement, research questions and aim of the study.

\section{History of climate change}

The science of CC has a relatively long history (Bhandari, 2018). Hamza et al. (2020) argue that there is sufficient historical proof to back the theory that CC is a natural occurrence. The term 'climate' is derived from the Greek word Klima, which means "inclination, the earth's expected slope toward the pole". Black (2013:1) argues that, "when it comes to CC science, the research underlying this perception has accumulated steadily over decades, similar to other major paradigm shifts". The first scientific observation related to this subject can be traced back to the French physicist Joseph Fourier, who discovered the natural greenhouse effect of the Earth in 1824.

\section{Understanding the climate change concept}

Many different schools of thought believe that CC is caused dominantly by anthropogenic and natural events (Jehanzaib et al., 2020). The CC subject remains a complex issue, which is differently defined. According to Hoogendoorn et al. (2020:1577), CC "is a combination of both natural events and human activities".

\section{Impact of climate change on the world}

There is no doubt that the planet's climate is changing and has been changing for thousands of years (Verichev et al., 2020; Kotir, 2010). According to Adil and Chohan (2020) as well as Dawson and Carson (2018), people worldwide are facing an uncertain future because of environmental issues that present a multitude of challenges, including human diseases, sea levels rising, economic impacts, ocean oxygen depletion and acidification, droughts, extreme weather events, arctic ice melting, and loss in biodiversity.

\section{Impact of climate change in Africa}

Africa has been identified as one region of the world most vulnerable to the impacts of CC (Edenhofer, 2014). The United Nations Environment Programme (2012) report suggests that numerous issues should be considered when relating the series of impacts and the underlying 
vulnerability of Africa to CC. Oduniyi (2013) states that the impact of CC on Africa is real and severe because of its high agricultural dependency and limited capacity to adapt. Baarsch et al. (2020) debate that $\mathrm{CC}$ is anticipated to have a harmfully effect on the African nations' economic development and that their income inequalities will subsequently continue to be the highest on the globe.

\section{The impact of climate change in sub-Saharan Africa}

Zewdie (2014) suggests that sub-Saharan Africa is more vulnerable to the effects of CC than any developing region in world. Southern Africa is a fast emerging region of great climatic, ecological, and cultural variety (Network of African Science Academies, 2015). In sub-Saharan Africa, the consequences of $\mathrm{CC}$ will be felt in many ways throughout human and natural systems.

The climate of the Southern African region is typified by changes in the severity, frequency, and length of weather extremes, causing recurring droughts, floods, and tropical cyclones in southern Africa (Kusangaya et al., 2021).

\section{The impact of climate change in South Africa}

Ziervogel et al. (2014) state that CC is a key concern for South Africa where yearly temperatures over the past five decades raised with 1.5 times the perceived universal average of $0.65{ }^{\circ} \mathrm{C}$. The South African rainfall patterns demonstrate high inter-annual changes and decreasing trends, even though CC as the cause is not statistically supported (Dube \& Nhamo, 2019). The 2016 drought that affected parts of South Africa is assumed to be the result of recently noticed CC (Masipa, 2017).South Africa is confronted with a population growth and CC-related challenges such as high temperatures, drought, and floods (Jude et al., 2019).

\section{Relationship between weather, natural disasters and climate change}

\section{Weather}

The United States Environmental Protection Agency (2018:16) report indicates that "weather is a condition that is normal but when its average pattern changes over time it could be an indication of CC". The Climate Council of Australia (2017) report suggests that heavy rain events, flooding, rising sea-levels, heat waves and bushfires are proof that relates weather to CC.

Disasters 
Several research studies shed more light on the link between CC and disasters (Neumayer \& Barthel, 2011). In the past two decades, CC-related natural disasters such as floods, hurricanes, and droughts have illustrated these links (Chen et al., 2020).

\section{Climate change responsibility}

The debate about who is responsible for $\mathrm{CC}$ has taken a central position on most global platforms, including the United Nations Framework Convention on CC. Some groups argue that large and industrialised countries must take full responsibility as they have a history of contributing to the highest proportion of emissions leading to CC (Frumhoff et al., 2015).

\section{The role of humans in climate change}

It is suggested that since the mid-19th century, human activities have largely increased greenhouse gases such as methane, carbon dioxide, and nitrous oxide, which resulted in CC (Rossati, 2017). Many climate ethicists argue that the conscience about climate-related matters requires basic morals and understanding of individually responsibility (Lahikainen, 2018).

\section{Human Behaviour Theory}

Swim et al. (2011) suggest that the reason for fast changes in global climate is attributed to human behaviour and the manner in which individuals think and reason. The nature of the ecosystem strongly depends on the patterns of human behaviour (Shafiei \& Maleksaeidi, 2020). To combat climate change, a behavioural change model inspired by CC education is needed (Stevenson et al., 2018).

\section{Climate change and students}

Pitpitunge (2013) suggests that students have a poor understanding and knowledge of CC. CC awareness by students is a necessary ingredient for a successful execution of CC laws (Oruonye, 2011). According to Mercer (2019), institutions such as the International Federation of Medical Students' Associations are already advocating for the universal inclusion of CC into the core curriculum by 2020 to spread CC awareness.

\section{Climate change education}

The United Nations Environment Scientific, Cultural Organisation (2013) perceives CC education as a largely unused strategic resource for constructing resilience and sustainable communities. Mochizuki and Bryan (2015) agree that CC education is vital and should be part of an international response in dealing with these complex challenges. 
Deisenrieder et al. (2020) share the same sentiments, stating that formal education often lacks effective CC education. Eilam et al. (2020) agrees that very little is known about how school curricula discuss the need to understand this crisis.

\section{Climate change and the general population}

Ajuang et al. (2016) suggest that the general public is conscious of global CC. Knight (2016) indicates that an increase in CC knowledge and perception among the general public could boost an understanding of $\mathrm{CC}$ and reduce the challenges of formulating international climate policies that are politically viable and effective. Only with the general public's broad acceptance and involvement, will the optimistic aims of reducing CC be accomplished (Schwirplies, 2018).

\section{Sources of information on climate change}

CC information is a vital driver for people to take personal or collective action to mitigate climate issues (Dong et al., 2018b). It is therefore of the utmost importance to choose the right communication channel when communicating CC issues. For example, Veltri and Atanasova (2015) suggest that an emotional text about CC is more likely to capture the attention of people than corporate media. Mavrodieva et al. (2019) agree that social networking outlets such as Instagram, Twitter, and Facebook have given the general public the ability to express views and participate in the $\mathrm{CC}$ debate as never before.

\section{Methodology}

Wong (2016) regards research methodology as important because it shows the plan on how the research problem will be addresses. It describes the action required to complete the study. It includes the research paradigm or philosophy, research strategy, research design, research methods, data collection and data analysis.

\section{Research philosophy}

\section{Ontology}

Al-Saadi (2014:1, citing Crotty, 1998) defines ontology as "the study of 'being' and is concerned with 'what is', i.e., the nature of existence and structure of reality as such". Objectivism has been selected. Ratner (2012: online) defines objectivism as "a view that an objective reality exists and can be known more through the gathering of more information. It is more practical and focuses more on facts from individually participants". For this reason this research is done from an objectivist perspective. 


\section{Epistemology}

A positivist approach was followed. Positivism is regarded as a philosophical approach only recognising that which is verified scientifically. It posits that a scientific approach is the only way to establish truth (Kawulich, 2012).

\section{Research approach}

According to Creswell and Plano Clark (2007:23), deductive researchers "work from the top down, from a theory to hypotheses to evidence to support or refute the theory". For this study a deductive approach was followed. The results cannot be generalised; it can only be applied to the University of Technology (UoT) studied.

\section{Research design}

According to Creswell (2014:113), research design is "an outline that has been formed to find answers to the research questions". It includes processes used for the collection and analysis of data. Quantitative research was adopted for this study. It emphasises collecting numerical data to explain a specific phenomenon. Quantitative methods focus on objective measurements using statistical and numerical analyses of collected data through surveys and questionnaires (Creswell, 2014).

\section{Research strategy}

The research strategy followed was that of a survey. Kendall (2011:31) argues that "a research survey is a tool in which the investigator gathers facts or attempts to determine the connection among facts". A survey is commonly used method, making it possible to study things that are not seen, such as the beliefs or attitudes of people. The unit of analysis was the students of a selected UoT in South Africa. The survey was structured to gained insight into the answers of the students on the research question and sub-research questions posed to them.

\section{Sample population}

The population is defined as the students of the District 6, Mowbrey, Athlone, and Bellville campuses of the selected UoT. The unit of analysis (UoA) was randomly selected (all students has an equal chance to be selected) (Saunders et al., 2019). Selected students on the campuses were approached to complete the questionnaire. Furthermore 1st, 2 nd, 3 rd and 4 th year students were sampled. In total, 603 students participated in the study; 127 were 1st year, 157 were 2 nd year, 152 were 3rd 
year, and 168 were 4th year students. The data collection and analysis were done under the supervision of the research supervisor.

\section{Data collection}

The survey questionnaire was used as a tool to collect data. The questionnaire was given to two experienced researchers, and after the inputs of the researchers have been incorporated, the questionnaire was piloted with students in the different sample clusters.

In order to obtain the required number of questionnaires, fieldworkers were recruited. A workshop was held to train the field workers. They worked on voluntary basis and no one was remunerated in any way. After each session of data collection, the field workers were debriefed to maintain the same standard of data collection and on what was needed to improve the clarity of the questionnaire.

\section{Data analysis}

The collected data were captured to an Excel spread sheet. SPSS and Microsoft Excel were used to analyse data. Exploratory factor analysis (EFA) was used to find hidden meanings.

\section{Results}

The chapter is divided into section A and section B. Section A presents the contribution figures of all the faculties and levels (from here on forward 'levels' and 'year of study' are used interchangeably) of studies in the institution. Section B presents CC-related questions and research hypotheses. The data were collected by means of a questionnaire, and then coded and analysed using Microsoft Excel and SPSS.

\section{Section A}

\section{Faculties}

This chapter presents the research results from the collected data and discusses the research findings. Students have been asked which faculty they represent to support the sampling method do as to ensure that all faculties were included in the survey. A total of 603 students participated in the study - 22\% (130) from Business and Management Sciences, 20\% (120) from Informatics and Design, 17\% (104) from Health and Wellness Sciences, 16\% (95) from Education, 13\% (81) from Engineering and Built Environment, and 12\% (73) from the Faculty of Applied Sciences. Table 1 display the numbers of students from the various faculties of the University of Technology. 
Table 1: Number of students per faculty who completed the survey

\begin{tabular}{|l|r|r|r|r|r|r|}
\hline Faculty & $\begin{array}{r}\text { Business and } \\
\text { Management } \\
\text { Sciences }\end{array}$ & $\begin{array}{r}\text { Applied } \\
\text { Sciences }\end{array}$ & $\begin{array}{r}\text { Informatics } \\
\text { and Design }\end{array}$ & Education & $\begin{array}{r}\text { Engineering } \\
\text { and Built } \\
\text { environment }\end{array}$ & $\begin{array}{r}\text { Health and } \\
\text { Wellness } \\
\text { Sciences }\end{array}$ \\
\hline $\begin{array}{l}\text { Number of } \\
\text { students (603) }\end{array}$ & 130 & 73 & 120 & 95 & 81 & 104 \\
\hline Percentage & $22 \%$ & $12 \%$ & $20 \%$ & $16 \%$ & $13 \%$ & $17 \%$ \\
\hline
\end{tabular}

\section{Student year of study}

The question was asked to ensure that all the years (levels) of study were included in the survey. Students who participated in the study were inclusive of all levels, from 1st year, 2nd year, 3rd year to 4 th year. Twenty-one percent (21\%) (127) of the students who participated were 1 st year, $26 \%$ (157) 2nd year, 25\% 3rd (152) year and 28\% (168) 4th year students. Table 2 and Figure 1 show the students numbers for each year level of study.

Table 2: Number of students per year of study

\begin{tabular}{|l|r|r|r|r|}
\hline Year of study (level) & $\mathbf{1}^{\text {st }}$ year & $\mathbf{2}^{\text {nd }}$ year & $\mathbf{3}^{\text {rd }}$ year & $\mathbf{4}^{\text {th }}$ year \\
\hline Number of respondents & 127 & 157 & 152 & 168 \\
\hline$\%$ & $21 \%$ & $26 \%$ & $25 \%$ & $28 \%$ \\
\hline
\end{tabular}

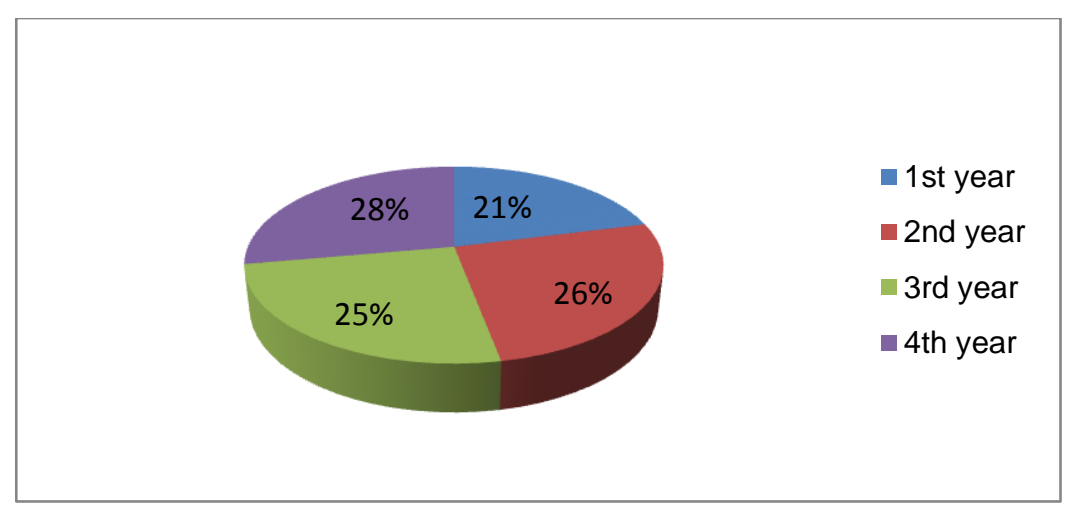

Figure 1: Number of students per year of study

\section{Section B}

This section sought to explore the students' awareness of CC and responding to the research questions.

\section{Climate change exists}

As a starting point, the question, "Do you think climate change exists?" was asked across faculties and year of study to explore the CC awareness of students. As shown in Table 4.3, 92\% of students acknowledged that CC exists, while a minority of 7\% did not. The response in Table 3 and Figure 2 show that the students are aware of the existence of CC. 
Table 2: Number of students responding to the existence of CC

\begin{tabular}{|l|r|r|r|}
\hline Response & Yes & No & No response \\
\hline Number of respondents & 555 & 45 & 3 \\
\hline$\%$ & $92 \%$ & $7 \%$ & $<1 \%$ \\
\hline \\
\end{tabular}

Figure 2: Number of students responding to the existence of CC

This may indicate that the students became aware of CC either before entering the university or during their university education.

\section{Climate change as a world problem}

The question, "Do you think climate change is the world's biggest problem?" aimed to assess the students' understanding of the impact of CC on the world. As reflected in Table 4, of the 603 students, $79 \%$ (477) suggested that CC is the biggest problem while $21 \%(126)$ stated the opposite. This is not surprising, as most students are aware of CC.

Table 3: Students' view on CC as the world's biggest problem

\begin{tabular}{|l|r|r|}
\hline Response & Yes & No \\
\hline Number of respondents & 477 & 126 \\
\hline$\%$ & $79 \%$ & $21 \%$ \\
\hline
\end{tabular}

\section{Causes of climate change}

The question, "What do you think is the cause of climate change?" was constructed to verify the students' perceptions of the contributions of countries, governments, corporations, businesses in general, and individuals to the causes of CC. Figure 3 show that $52 \%$ (316) of the students pointed to large countries, governments, large corporates, businesses and individuals as the major sources (causes) of CC. In total, 20\% (122) suggested that individuals are responsible, 6\% (39) indicated businesses in general, 7\% (44) indicated large corporates, 2\% (15) pointed to governments, 9\% (54) indicated large countries, and 1\% (7) opined that large countries and large corporates together are responsible for CC. Thus, all the role players were seen as responsible for CC. This is per se not useful - the question should have been posed differently. 


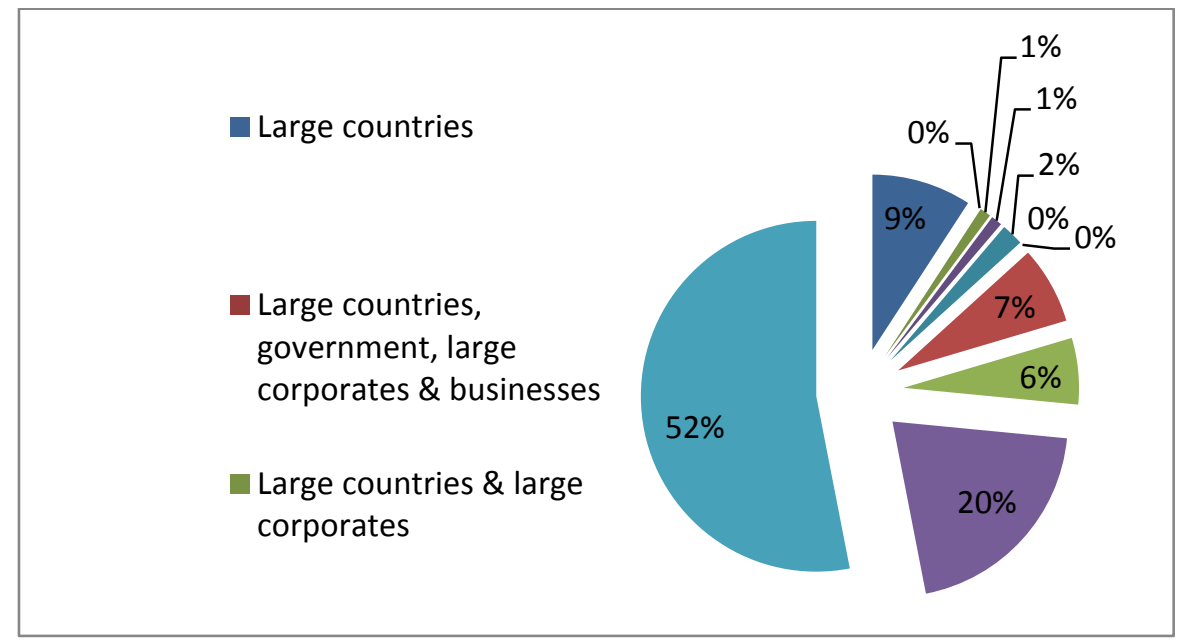

Figure 3: Role players contributing to $\mathrm{CC}$ as indicated by students

It is evident from the responses that the students place the blame of $\mathrm{CC}$ on a range of organisations and individuals. Again, this is to be expected as the students are aware of CC

\section{Students' perceptions on their level of CC awareness}

The question, "On a scale of 1 to 5, how would you rate your level of awareness of climate change?" aimed to measure the level at which students perceived their understanding of CC. As seen in Table 4.7 and Figure $4.8,10 \%$ of students rated their level of CC understanding as poorly. Eighteen percent (18\%) indicated that they are only a little aware of CC, $30 \%$ (179) said they have an idea of CC, $29 \%$ (177) stated that they are aware of CC, and $13 \%$ (77) opined that they are very aware of CC. The response to this question is a surprise, especially when taking into account the answers of the previous questions. When students were asked a more general question, e.g. "Do you think climate change exists?" compared to a questions on CC awareness with more options, the students were less certain of their level of awareness, ranging from 'having an idea' to 'very aware'.

Table 5: Students' perceived level of CC awareness

\begin{tabular}{|l|r|r|r|r|r|}
\hline Scale & Poor & Little aware & I have an idea & Aware & Very aware \\
\hline Number of respondents & 59 & 111 & 179 & 177 & 77 \\
\hline & & & & & \\
\hline
\end{tabular}




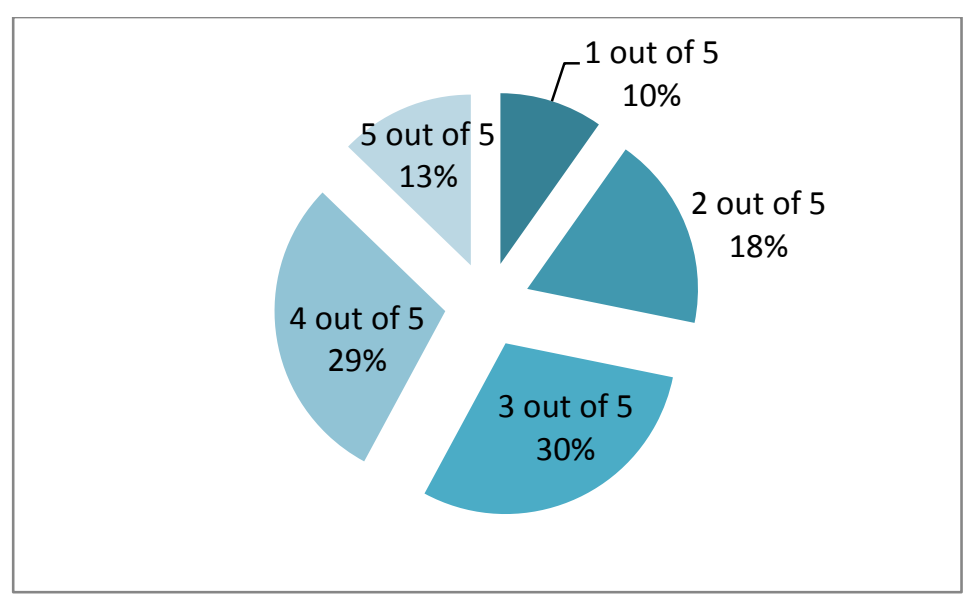

Figure 4: Students' perceived level of CC awareness

\section{The role students' level of study plays in understanding climate change}

The question, "Does your level of study play any role in how you understand climate change?" was asked to explore the students' perception of whether the level (year) of study plays a role in the awareness and understanding of CC. As indicated in Table 6 and Figure 5, 52\% (314) of students said they believe that level of education plays a significant role in understanding CC, while $48 \%$ (289) suggested the level of study does not really matter. The results surprisingly indicate a level of uncertainty whether education plays an important role in the CC awareness of students.

Table 6: Role of the level of education in CC awareness

\begin{tabular}{|l|r|r|}
\hline Response & Yes & No \\
\hline Number of respondents & 314 & 289 \\
\hline$\%$ & $52 \%$ & $48 \%$ \\
\hline
\end{tabular}

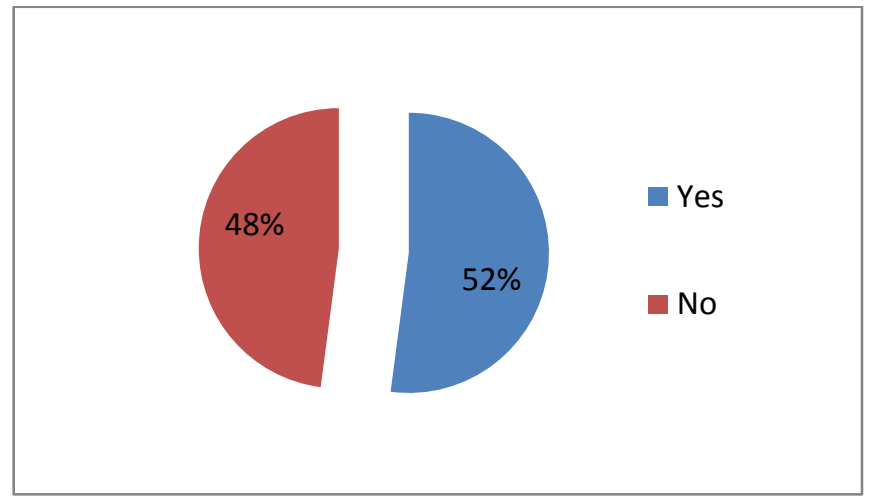

Figure 5: Role of the level of education in CC awareness 


\section{The influence of students' personal background on climate change awareness}

"Do you think your personal background has an influence on the way you understand climate change?" This question was asked to determine students' perceptions on whether their background has any effect on their CC awareness level. As illustrated in Table 7, 70\% (422) of the students said their personal background does have an effect on their awareness of CC, while 30\% (181) felt the opposite. This indicates that the way students are raised may play a role in their awareness of CC.

This is not surprising, as the data show that TV and social media play an important role in creating CC awareness. Taking into account the socio-economic disparity in South Africa, where for example TV and social media are not freely available to all citizens, it makes sense that the background of the students may greatly vary.

Table7: Personal background influence on $\mathrm{CC}$ awareness

\begin{tabular}{|l|r|r|}
\hline Response & Yes & No \\
\hline Number of respondents & 422 & 181 \\
\hline$\%$ & $70 \%$ & $30 \%$ \\
\hline
\end{tabular}

\section{The lack of education in the awareness of climate change}

The statement, "Lack of climate change education is a major contributor to students' awareness of climate change" was posed to determine if the curriculum presented at the University of Technology assists with creating CC awareness within faculties and at different levels of education. Table 8 indicate that $47 \%$ (285) of the students strongly agreed that the lack of CC education at the university is a major contributor towards the lack of student awareness of CC, while $37 \%$ (221) somewhat agreed.

However, $13 \%$ (76) somewhat disagreed, while 3\% (21) strongly disagreed. This shows that CCrelated education is necessary to improve the awareness of students about CC, which is a surprise finding as it is expected that universities in general would teach at least to some degree the importance of $\mathrm{CC}$ and the impact on the planet.

Table 8: Lack of CC education as major contributor to students' CC awareness

\begin{tabular}{|l|r|r|r|r|}
\hline Response & Strongly agree & $\begin{array}{r}\text { Somewhat } \\
\text { agree }\end{array}$ & $\begin{array}{r}\text { Somewhat } \\
\text { disagree }\end{array}$ & $\begin{array}{r}\text { Strongly } \\
\text { disagree }\end{array}$ \\
\hline $\begin{array}{l}\text { Number } \\
\text { respondents }\end{array}$ & 285 & 221 & 76 & 21 \\
\hline$\%$ & $47 \%$ & $37 \%$ & $13 \%$ & $3 \%$ \\
\hline
\end{tabular}




\section{Human behaviour and climate change}

The statement, "Human behaviour is responsible for climate change", has been made to determine the students' views on human behaviour affecting CC. As shown in Table 9 , 55\% (329) of the students strongly agreed that human behaviour is more responsible for changes in the climate, $32 \%$ (191) somewhat agreed, $11 \%$ (67) somewhat disagreed, and 3\% (16) strongly disagreed. The students are aware that human behaviour is contributing towards CC.

Unfortunately, this research did not further explore the matter in terms of determining what type of behaviour is responsible for $\mathrm{CC}$ and how this behaviour can be changed. These challenges need further research.

Table 9: Students' view on human behaviour affecting CC

\begin{tabular}{|l|r|r|r|r|}
\hline Response & Strongly agree & $\begin{array}{r}\text { Somewhat } \\
\text { agree }\end{array}$ & $\begin{array}{r}\text { Somewhat } \\
\text { disagree }\end{array}$ & Strongly disagree \\
\hline $\begin{array}{l}\text { No. of } \\
\text { respondents }\end{array}$ & 329 & 191 & 67 & 16 \\
\hline$\%$ & $55 \%$ & $32 \%$ & $11 \%$ & $3 \%$ \\
\hline
\end{tabular}

H1: Students who are aware of climate change are more likely to study in some faculties rather than others

The hypotheses assessed whether the students believe in the existence of CC by comparing two variables, 'faculties' and 'CC existence'. It seems that some areas of study are more likely to include CC than others.

Table 10: One-sample Chi-Square test summary for $\mathrm{H}_{1}$

\begin{tabular}{|l|r|}
\hline Total N & 557 \\
\hline Test Statistic & $18.558^{\mathrm{a}}$ \\
\hline Degree of Freedom & 5 \\
\hline Asymptotic Sig. (2-sided test) & .002 \\
\hline $\begin{array}{l}\text { a There are 0 cells (0\%) with expected values less than 5. } \\
\text { The minimum expected value is 92.833. }\end{array}$ \\
\hline
\end{tabular}




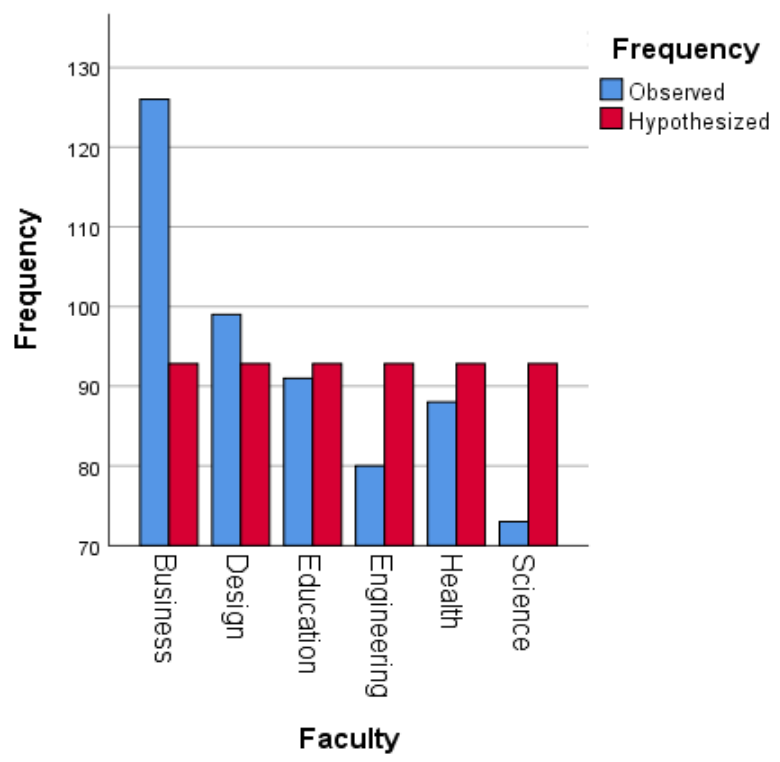

Figure 6: One-sample Chi-Square test summary for $\mathrm{H}_{1}$

The Chi-Square goodness-of-fit test shows that $\mathrm{H}_{0}$ can be rejected ( $\mathrm{N}=557, \mathrm{DF}=5, \mathrm{p}=0.002$ ), i.e. the students are not evenly distributed across faculties.

H2: The number of students who believe in climate change is likely to increase as they progress through university

This hypothesis aimed to compare the different CC awareness levels of students as they progress with their studies by comparing their 'year of study' and 'CC existence'.

Table 11: One-sample Chi-Square test summary $\mathrm{H}_{2}$

\begin{tabular}{|c|c|}
\hline Total N & 557 \\
\hline Test Statistic & $4.113^{a}$ \\
\hline Degree of Freedom & 3 \\
\hline Asymptotic Sig. (2-sided test) & .250 \\
\hline
\end{tabular}




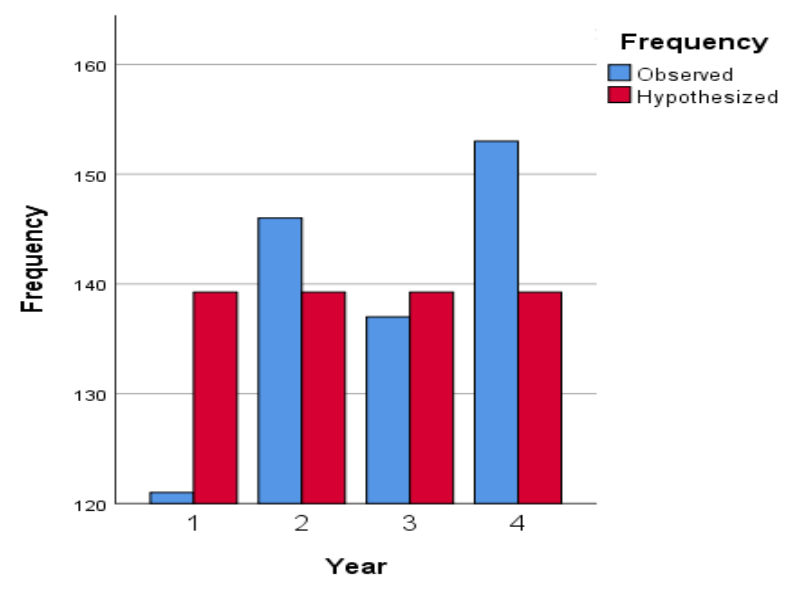

Figure 7: One-sample Chi-Square test summary for $\mathrm{H}_{2}$

The Chi-Square goodness-of-fit test shows that $H_{0}$ cannot be rejected $(N=557, D F=e, p=0.25)$, i.e. there is a relationship between students' belief in CC and their year of study (Table 11; Figure 7).

\section{Findings}

The research findings suggest that majority of students are aware of climate change. Students acknowledge that climate change is the world's biggest problem. Large countries, governments, large corporates, businesses and individuals are seen as the major causes of climate change. The rise in the planet's temperature is a major challenge created by climate change. Most respondents became aware of climate change through TV

\section{Discussions}

The majority (92\%) of students are to some level aware of CC. The results show that students do not fully realise the impact of $\mathrm{CC}$ on humans and the planet, which is in agreement with Salehi et al.'s (2016) findings that students have a moderate awareness of the CC phenomenon.

It can be concluded that students who are aware of CC, even if it is only to some extent, perceive CC as one of the world's biggest challenges. Rocklöv et al. (2021) agree with the study's findings that CC is a well-known 21st century global problem.

Students suggest that an individual's background contributes to the awareness of $\mathrm{CC}$, and that this plays are role in CC awareness. Nguyen et al. (2016) report that variations in students' CC awareness are influenced by personal background, socio-cultural and institutional contexts, as well as their views on the perceived impact of CC and their understanding of the factors that play an important role in the $\mathrm{CC}$ awareness, as $\mathrm{CC}$ is attributed to human actions. 
The first finding states that most students became aware of CC by watching television (TV), which, in their opinion, is a preferred and good source for conveying the message of CC awareness. This supports Chukwuji et al. (2019) finding that television is a major source of CC information.

It was found that students in the Business Faculty are more aware of CC than students in other faculties. This is surprising, as Business faculties are usually teaching CC or environment related matters the least, while Science students are usually more informed. This is contrary to the findings of Blackmore et al. (2018), who argue that students in Business and Management are taught the least about CC-related problems, while students in General Sciences and Environmental Science are more exposed to information on CC.

The finding that the year of study increases students' level of CC awareness is not surprising, as it is expected that the more a student progresses, the more the student becomes knowledgeable on CC. It is not clear which levels of study include CC in the curriculum. According to Ajuang et al. (2016), one's level of education has a huge impact on CC awareness.

$\mathrm{CC}$ of the general public has become a political matter. Some citizens regard $\mathrm{CC}$ as a myth, while other are politicising it as non-existent. CC is polarising politics throughout, where right-wing political parties and agendas have been linked to a lack of concern about CC. As a result, right-wing populism in various regions and nations, such as the United States, Australia, and Europe, appears to be anti-climate policy (McCright et al., 2015). However, regardless of this political polarisation, the findings of this research show that students are concerned about CC as they regard it as the world's biggest problem. This is evident by the renewed activism of students, as, since 2018, millions of students in the world took the struggle of CC to the streets, protesting against governments and requiring them to take action (Von Storch et al., 2021). This generation of students has made their voices heard, clearly raising their concerns about CC challenges that will ultimately affect their future (Wallis \& Loy, 2021). Today's younger students' future lifestyles and pro-environmental behaviour will be a critical factor in reducing the severity of predicted CC (Lehnert et al., 2019). For students and youth to comprehend CC and its expected consequences, they need to be educated on CC.

The findings show that students are particularly concerned about the increase in temperature as an effect of CC. Student thinking on the CC system is significantly linear, i.e., human activity triggers global rising temperatures, which eventually has an effect on humans themselves (Handayani \& Putra, 2019). The average global temperature is slowly rising and is expected to increase by $20 \mathrm{C}$ by the year 2100, resulting in a major climate crisis (Malhi et al., 2021). 


\section{Conclusion}

The study was conducted at one the Universities of Technology in the Western Cape, South Africa. The majority of this university's students are aware of climate change, according to the results of the study. Notwithstanding the restriction of conducting the study at only one university, which is not representative of all South African universities, it provided sufficient exposure to CC knowledge among the university's students. CC awareness can play an important role in shaping students' proenvironmental attitudes and empowering them to fight the negative effects of $\mathrm{CC}$ in the country and throughout the globe.

\section{Recommendations}

A coordinated national strategy is needed in all tertiary institutions. The current curriculum should be reviewed to include CC. Universities should appoint environmental officers to seat in all their curriculum decision making forums. An introduction of weekly CC awareness campaigns is necessary. Universities should introduce special modules dealing with CC at all levels, or integrate CC into existing modules.

\section{Suggestions for further research}

This study focused only on students of one University of Technology. Future research is needed to assess the CC level of awareness of students at other universities in South Africa. There is also a need for research on the relationship between CC and the curricula offered by universities. Further research could also be done with TVET college students as participants to expand the scope to all tertiary institutions.

\section{Acknowledgement}

The research author wishes to thank his research supervisor Dr Andre de la Harpe for his wisdom, mentorship and guidance throughout the research journey.

\section{References}

Adil, A. \& Chohan, U.W. 2020. Climate change as socioeconomic threat: International Perspectives. CASS Working Papers on Environmental Security, 2020. Centre for Aerospace \& Security Studies (CASS). https://doi.org/10.2139/ssrn.3544582.

Agboola, O.S. \& Emmanuel, M. 2016. Awareness of climate change and sustainable development among undergraduates from two selected universities in Oyo State, Nigeria. World Journal of Education, 6(3):1. 
Ajuang, C.O., Abuom, P.O., Bosire, E.K., Dida, G.O. \& Anyona, D.N. 2016. Determinants of climate change awareness level in upper Nyakach Division, Kisumu County, Kenya. SpringerPlus, 5:1015 (2016). https://doi.org/10.1186/s40064-016-2699-y.

Ajuang, C.O., Abuom, P.O., Bosire, E.K., Dida, G.O. \& Anyona, D.N. 2016. Determinants of climate change awareness level in upper Nyakach Division, Kisumu County, Kenya. SpringerPlus, 5:1015 (2016). https://doi.org/10.1186/s40064-016-2699-y

Baarsch, F., Granadillos, J.R., Hare, W., Knaus, M., Krapp, M., Schaeffer, M. \& Lotze-Campen, H. 2020. The impact of climate change on incomes and convergence in Africa. World Development, 126:104699. https://doi.org/10.1016/j.worlddev.2019.104699.

Barreda, A.B. 2018. Assessing the level of awareness on climate change and sustainable development among students of Partido State University, Camarines Sur, Philippines. The Journal of Sustainable Development, 17: online.

Bhandari, M. 2018. Climate change science: A historical outline. Advances in Agriculture and Environmental Science: Open Access (AAEOA), 1(1):5-12. https://doi.org/10.30881/aaeoa.00002.

Black, R. 2013. A brief history of climate change. BBC News. Available: http://www.bbc.com/news/science-environment-15874560. [Accessed: 16 May 2020].

Blackmore, Holly., Harrington, C., Letchford, C. \& Martin, F. 2018. Perceptions of climate change: How Dalhousie students conceptualise climate change and the role of faculty in promoting awareness. Available: https://dalspace.library.dal.ca/handle/10222/76644. [Accessed: 11 November 2020].

Chen, S., Bagrodia, R., Pfeffer, C.C., Meli, L. \& Bonanno, G.A. 2020. Anxiety and resilience in the face of natural disasters associated with climate change: A review and methodological critique. Journal of Anxiety Disorders, 76:102297. https://doi.org/10.1016/j.janxdis.2020.102297.

Chukwuji, C. N., Tsafe, A.G., Sayudi, S., Yusuf, Z. \& Zakariya, J. 2019. Awareness, access and utilisation of information on climate change by farmers in Zamfara State, Nigeria. Library Philosophy and Practice (e-Journal), 1(7):216-226.

Creswell, J.W. \& Plano Clark, V.L. 2007. Designing and conducting mixed methods research. Thousand Oaks, CA: Sage.

Creswell, J.W. 2014. Research design: Qualitative, quantitative and mixed methods approaches. $4^{\text {th }}$ ed. London: Sage.

Deisenrieder, V., Kubisch, S., Keller, L. \& Stötter, J. 2020. Bridging the action gap by democratizing climate change education-The Case of k.i.d.Z.21 in the context of Fridays for future. Sustainability, 12(5):1748. https://www.mdpi.com/2071-1050/12/5/1748.

Dong, C., Dong, X., Jiang, Q., Dong, K. \& Liu, G. 2018. What is the probability of achieving the carbon dioxide emission targets of the Paris Agreement? Evidence from the top ten emitters. Science of the Total Environment, 1:622-623, 1294-1303. https://doi.org/10.1016/j.scitotenv.2017.12.093. 
Dube, K. \& Nhamo, G. 2019. Evidence and impact of climate change on South African National Parks. Potential implications for tourism in the Kruger National Park. Environmental Development, 33:100485. https://doi.org/10.1016/i.envdev.2019.100485.

Edenhofer, O., Pichs-Madruga, R., Sokona, Y., Farahani, E., Kadner, S., Seyboth, K., Adler, A., Baum, I. et al. (eds.). 2014. Climate Change 2014: Mitigation of climate change. Contribution of Working Group III to the Fifth Assessment Report of the Intergovernmental Panel on Climate Change. Cambridge University Press.

Edwards, D. 2020. Editorial overview: Feeding a warming planet. Current Opinion in Plant Biology, 56:A5-A6. https://doi.org/10.1016/j.pbi.2020.08.001.

Eilam, E., Prasad, V. \& Widdop, Q.H. 2020. Climate change education: Mapping the nature of climate change, the content knowledge and examination of enactment in upper secondary Victorian curriculum. Sustainability, 12(2):591. https://doi.org/10.3390/su12020591/.

Frumhoff, P.C., Heede, R. \& Oreskes, N. (2015). The climate responsibilities of industrial carbon producers. Climatic Change, 132:157-171. https://doi.org/10.1007/s10584-015-1472-5.

Gordon, D. 2020. Sustainability in the operating room. Anaesthesiology Clinics, 38(3):679-692. https://doi.org/10.1016/j.anclin.2020.06.006.

Handayani, R.D. \& Putra, P.D.A. 2019. Student cognition in the context of a climate system: Global warming and greenhouse effect. Momentum: Physics Education Journal, 3(2):69-77. https://doi.org/10.21067/mpej.v3i2.3739.

Hoogendoorn, G., Sütterlin, B. \& Siegrist, M. 2020. The climate change beliefs fallacy: The influence of climate change beliefs on the perceived consequences of climate change. Journal of Risk Research, 23(12):1577-1589. https://doi.org/10.1080/13669877.2020.1749114.

Jamshidi, O., Asadi, A., Kalantari, K. \& Azadi, H. 2018. Perception, knowledge, and behaviour towards climate change: A survey among agricultural professionals in Hamadan Province Iran. Journal of Agricultural Science, 20(7):1369-1382.

Jehanzaib, M., Shah, S.A., Kwon, H.H. \& Kim, T.W. 2020. Investigating the influence of natural events and anthropogenic activities on hydrological drought in South Korea. Terrestrial, Atmospheric and Oceanic Sciences, 31(1):85-96. https://doi.org/10.3319/tao.2019.08.13.01.

Jude, M.L., Alban, D.L., Johan, T., Malin, B., Johan, S., Alena, B. \& Berit, A. 2019. The impact of climate change on the water quality in the KwaZulu-Natal province of South Africa. EGU General Assembly Conference Abstracts. Available:

https://ui.adsabs.harvard.edu/abs/2019EGUGA..2117049L/abstract. [Accessed: 1 April 2020].

Kawulich, B. 2012. Selecting a research approach: Paradigm, methodology and methods. In Wagner C., Kawulich B., \& Garner M. (eds.), Doing social research: A global context. McGraw Hill, 5161.

Kendall, D. 2011. Sociology in our times: The essentials . $8^{\text {th }}$ ed. Cengage Learning. 
Kennedy C. \& Lindsey, R. 2015. What's the difference between global warming and climate change? Available: https://www.climate.gov/news-features/climate-qa/whats-difference-betweenglobal-warming-and-climate-change. [Accessed: 6 March 2019].

Knight, K.W. 2016. Public awareness and perception of climate change: A quantitative cross-national study. Environmental Sociology, 2(1):101-113. https://doi.org/10.1080/23251042.2015.1128055.

Kotir, J.H. 2010. Climate change and variability in sub-Saharan Africa: A review of current and future trends and impacts on agriculture and food security. Environment, Development and Sustainability: A Multidisciplinary Approach to the Theory and Practice of Sustainable Development, 13(3):587-605. http://hdl.handle.net/10.1007/s10668-010-9278-0

Kusangaya, S., Mazvimavi, D., Shekede, M.D., Masunga, B., Kunedzimwe, F. \& Manatsa, D. 2021.Climate change impact on hydrological regimes and extreme events in Southern Africa. In Diop S., Scheren P. \& Niang A. (eds.), Climate change and water resources in Africa. Cham: Springer. https://doi.org/10.1007/978-3-030-61225-2_5

Lahikainen, L. 2018. Individual responsibility for climate change: A social structural account. Academic Dissertation, University of Tampere, Finland.

Lehnert, M., Fiedor, D., Frajer, J., Hercik, J. \& Jurek, M. 2019. Czech students and mitigation of global warming: Beliefs and willingness to take action. Environmental Education Research, 26(6):864889. https://doi.org/10.1080/13504622.2019.1694140.

Malhi, G.S., Kaur, M. \& Kaushik, P. 2021. Impact of climate change on agriculture and its mitigation strategies: A Review. Sustainability, 13(3):1318. https://doi.org/10.3390/su13031318.

Masipa, T. 2017. The impact of climate change on food security in South Africa: Current realities and challenges ahead. Jàmbá: Journal of Disaster Risk Studies, 9(1): online. https://dx.doi.org/10.4102/jamba.v9i1.411

Mavrodieva, A.V., Rachman, O.K., Harahap, V.B. \& Shaw, R. 2019. Role of social media as a soft power tool in raising public awareness and engagement in addressing climate change. Climate, 7(10):122. https://doi.org/10.3390/cli7100122.

McCright, A.M., Dunlap, R.E. \& Marquart-Pyatt, S.T. 2015. Political ideology and views about climate change in the European Union. Environmental Politics, 25(2):338-358. https://doi.org/10.1080/09644016.2015.1090371.

Mercer, C. 2019. Medical students call for more education on climate change. Canadian Medical Association Journal, 191(10):E291-E292. https://doi.org/10.1503/cmaj.109-5717.

Mochizuki, Y. \& Bryan, A. 2015. Climate change education in the context of education for sustainable development: Rationale and principles. Journal of Education for Sustainable Development, 9(1):4-26. https://doi.org/10.1177/0973408215569109.

Mugambiwa, S.S. \& Dzomonda, O. 2018. Climate change and vulnerability discourse by students at a South African university. Jàmbá: Journal of Disaster Risk Studies, 10(1):476. https://doi.org/10.4102/jamba.v10i1.476. 
Narksompong, J. \& Limjirakan, S. 2015. Youth participation on climate change for sustainable development. RECIEL: Special Issue: Public Participation and Climate Governance, 24(2):171181. https://doi.org/10.1111/reel.12121.

Network of African Science Academies (NASAC). 2015. Climate change adaptation and resilience in Africa - Recommendations to policymakers. NASAC e-bulletin, 2(2): online.

Neumayer, E. \& Barthel, F. 2011. Normalising economic loss from natural disaster: a global analysis. Global Environmental Change, 21(1):13-24.

Nguyen, T.P.L., Seddaiu, G., Virdis, S.G.P., Tidore, C., Pasqui, M. \& Roggero, P.P. 2016. Perceiving to learn or learning to perceive? Understanding farmers' perceptions and adaptation to climate uncertainties. Agricultural Systems, 143:205-216. https://doi.org/10.1016/j.agsy.2016.01.00.

O'Brien, K., Selboe, E. \& Hayward, B.M. 2018. Exploring youth activism on climate change: Dutiful, disruptive, and dangerous dissent. Ecology and Society, 23(3):2-4. https://doi.org/10.5751/es10287-230342.

Oduniyi, O.S. 2013. Climate change awareness: A case study of small scale maize farmers in Mpumalanga Province. Master's Dissertation, UNISA.

Oruonye, E.D. 2011. An assessment of the level of awareness of the effects of climate change among students of tertiary institutions in Jalingo Metropolis, Taraba State Nigeria. Journal of Geography and Regional Planning, 4(9):513-517. https://doi.org/10.5897/JGRP.9000012

Pitpitunge, A.D. 2013. Students' perceptions about climate change. Asian Journal of Biology Education, 7:1-10.

Ratner, C. 2012. Methodological holism versus individualism. In Given L.M. (ed.), The Sage Encyclopedia of Qualitative Research Methods. Sage.

Rocklöv, J., Ahlm, C., Scott, M.E. \& Humphries, D.L. 2021. Climate change pathways and potential future risks to nutrition and infection. In Humphries D.L., Scott M.E. \& Vermund S.H. (eds.), Nutrition and infectious diseases. Nutrition and health. Cham: Humana. https://doi.org/10.1007/978-3-030-56913-6_15.

Rossati, A. 2017. Global warming and its health impact. The International Journal of Occupational and Environmental Medicine, 8(1):7-20. https://doi.org/10.15171/ijoem.2017.963

Rother, H.A. \& Godsmark, C.N. 2018. Literature review assessing climate change risks and impacts on the health sector in the Western Cape, South Africa. Available:

https://www.westerncape.gov.za/eadp/files/atoms/files/Health\%20\%26\%20CC\%20Literature \%20Review\%2020180702.pdf [Accessed: 21 Feb 2019].

Salehi, A., Nejad, Z.P., Mahmoudi, H. \& Burkart, S. 2016. Knowledge of global climate change: View of Iranian university students. International Research in Geographical and Environmental Education, 25(3):226-243. https://doi.org/10.1080/10382046.2016.1155322.

Saunders, M., Lewis, P., Thornhill, A. \& Bristow, A. 2019. Understanding research philosophy and approaches to theory development. In Research methods for business students. $8^{\text {th }}$ ed. Pearson Education. 
Schwirplies, C. 2018. Citizens' acceptance of climate change adaptation and mitigation: A survey in

China, Germany, and the US. Ecological Economics, 145:308-322.

https://doi.org/10.1016/j.ecolecon.2017.11.003

Shafiei, A. \& Maleksaeidi, H. 2020. Pro-environmental behaviour of university students: Application of protection motivation theory. Global Ecology and Conservation, 22:e00908. https://doi.org/10.1016/j.gecco.2020.e00908.

Stevenson, K.T., Nils Peterson, M. \& Bondell, H.D. 2018. Developing a model of climate change behaviour among adolescents. Climatic Change, 151(3-4):589-603. https://doi.org/10.1007/s10584-018-2313-0.

Swim, J.K., Clayton, S. \& Howard, G.S. 2011. Human behavioural contributions to climate change: Psychological and contextual drivers. American Psychologist, 66(4):251-264. https://doi.org/10.1037/a0023472

Trott, C.D. 2021. What difference does it make? Exploring the transformative potential of everyday climate crisis activism by children and youth. Children's Geographies, Forthcoming Special Issue: Everyday Climate Crisis Activism. https://doi.org/10.1080/14733285.2020.1870663.

United Nations Environment Programme (UNEP). 2012. UNEP 2012 annual report. Available: https://www.unep.org/resources/annual-report/unep-2012-annual-report [Accessed: 30 January 2020].

Veltri, G.A. \& Atanasova, D. 2015. Climate change on Twitter: Content, media ecology and information sharing behaviour. Public Understanding of Science, 26(6):721-737. https://doi.org/10.1177/0963662515613702.

Verichev, K., Zamorano, M. \& Carpio, M. 2020. Effects of climate change on variations in climatic zones and heating energy consumption of residential buildings in the Southern Chile. Energy and Buildings, 215:109874. https://doi.org/10.1016/j.enbuild.2020.109874.

Von Storch, L., Ley, L. \& Sun, J. 2021. New climate change activism: Before and after the COVID-19 pandemic. Social Anthropology, 29(1):205-209. https://doi.org/10.1111/1469-8676.13005.

Wallis, H. \& Loy, L.S. 2021. What drives pro-environmental activism of young people? A survey study on the Fridays For Future Movement. Journal of Environmental Psychology, 74:101581. https://doi.org/10.1016/j.jenvp.2021.10158.

Wong, P.T. 2016. How to write a research proposal. Available: http://www.drpaulwong.com/how-towrite-a-research-proposal/ [Accessed: 17 March 2021].

Zewdie, A. 2014. Impacts of Climate Change On Food Security: A Literature Review in sub-Saharan Africa. Journal of Earth Science \& Climatic Change, 5(8):225. https://doi.org/10.4172/21577617.1000225 .

Ziervogel, G., New, M., Archer van Garderen, E., Midgley, G., Taylor, A., Hamann, R., Stuart-Hill, S., Myers, J. et al. 2014. Climate change impacts and adaptation in South Africa. Wiley Interdisciplinary Reviews: Climatic Change, 5(5):605-620. https://doi.org/10.1002/wcc.295. 